\title{
Comparative growth of primary schoolchildren from one and two parent families
}

\author{
A R GARMAN, S CHINN, AND R J RONA
}

\author{
Department of Community Medicine, St Thomas's Hospital Medical School, London
}

SUMmaRY Data drawn from the National Study of Health and Growth enabled an examination to be made of the attained height, weight for height, and triceps skinfold of children from one and two parent families. Children from one parent families were shorter than children from two parent families; however, once heights had been adjusted for birthweight, number of siblings, mother's height, father's height, and mother's education this was no longer the case. An examination of the adjusting factors showed that low birthweights and shorter parents accounted for the shorter stature of the one parent family children. An examination of weight for height and triceps skinfold measurements indicated an increased tendency towards obesity in the one parent family children, although this difference was not statistically significant. The higher prevalence of low birthweights and shorter parents that account for the shorter stature of one parent children are factors that cannot be ignored in a consideration of the health and growth of this group of children and obesity may be a potential health problem among the one parent family children.

The number of illegitimate births, expressed as a proportion of all births in England and Wales, has risen from about $8 \%$ in the early 1970 s to nearly $11 \%$ in 1979.1 This trend coupled with a rising divorce rate $(67000$ more divorces were granted in 1979 than in 1971) $)^{1}$ has resulted in a substantial group of one parent families in the population. In 1979 in Great Britain $12 \%$ of all children in the population were from one parent families as reported by the Central Statistical Office in $1980 .^{1}$ This group comprises mother-headed and father-headed families, the latter being in the minority and the majority of mother headed families being a result of divorce and separation.

Children from mother-headed one parent families-whether as a result of unmarried motherhood, widowhood, divorce, or separation-are subject to stresses and strains, and are thought to constitute an 'at risk' group in the population with regard to health and growth. Previous work on one parent families has concentrated on the study of such stresses and strains-for example, financial ${ }^{2-4}$ and housing ${ }^{2} 5$-rather than the study of the outcome of such stresses and strains on health and growth.

It is known that there are differences in attained height $^{67}$ and weight ${ }^{89}$ between social groups. We have therefore studied data from the National Study of Health and Growth (NSHG) to determine whether there is an association between the number of parents living in the household and attained height and weight of the children of these families.

\section{Methods}

The NSHG, which began in 1972, is a mixed longitudinal study of children aged between 5 and 11 years attending primary school. Twenty-eight areas in England and Scotland were chosen by stratified random sampling, with proportionately more areas from poorer social groups. ${ }^{10}$ The annual sample is defined as all pupils of selected primary schools within these areas, the same schools being visited each year. The height, weight, and triceps skinfold measurements of the children are taken once a year, and 2 weeks before the measurement session parents are asked to complete a questionnaire of social information.

In the cross-sectional analysis data were obtained from 5658 children who participated in the NSHG in 1977 , the first year in which information as to whether the child's family was a one or two parent family was sought. Changes in the questionnaire in 1977 however, meant that details of mother's education, parents' weights and heights had to be obtained from 1976 questionnaires and therefore only children who had taken part in the study in both years were included in this analysis. The Figure shows the number of these 5658 children 


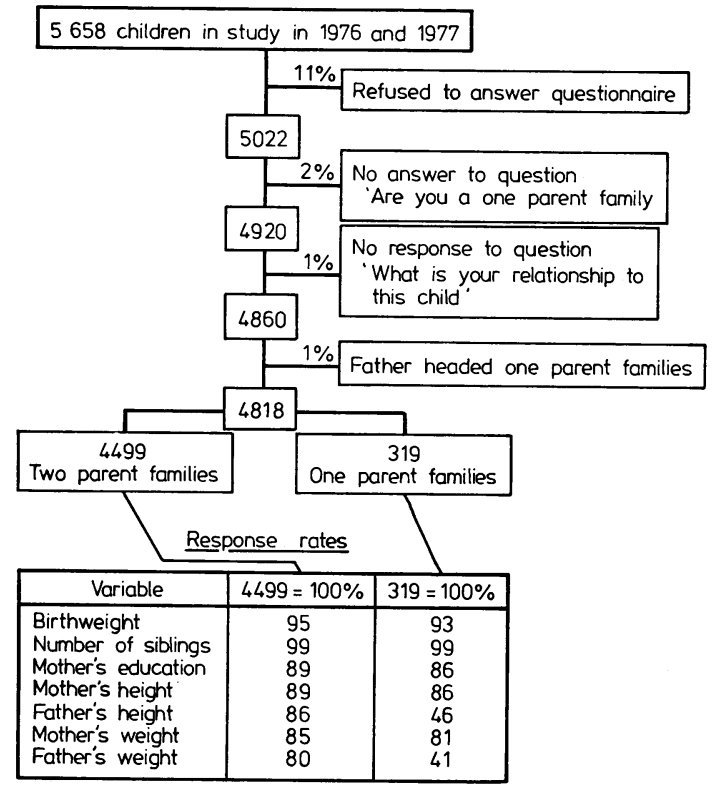

Figure Number of children in the analyses and response rates per variable according to number of parents.

whose data were not included in the analysis with the reasons for their exclusion.

Separate analyses were made of attained height, triceps skinfold, and weight adjusted for height and age, ${ }^{11}$ the last two measures being proxies of obesity in childhood. The properties of these proxy measures were discussed by Morris and Chinn.12 Many of our results are expressed in standard deviation (SD) scores. These scores were calculated for each child as the difference between a child's own measurement and the mean measurement in 1977 of children of the same age, sex, and country of residence (Scotland or England), divided by the SD for these children. This method removes the effects of age, sex, and country, and standardises for the increasing variance of the measurements between ages 5 and 11 years. As the distributions of weight and triceps skinfold were positively skewed, before calculating the appropriate SD score, the transformations log (measurement-constant) were used to normalise these distributions. 1113

The social and biological factors were: child's birthweight; number of children in the family; mother's education (as a proxy measure of social class); parents' heights; and, in the case of the obesity measures: parents' weights and child's ethnic origin. These independent variables are known to be significantly associated with height and weight and account for most of the explicable variation in the height and weight of children. ${ }^{714}$

Preliminary analysis involved firstly a comparison of children's heights, triceps skinfolds, and weight for heights in one and two parent families, and secondly an analysis was made of these measurements in relation to the selected social and biological factors, to determine whether the associations of these factors and the three measurements were the same in the one and two parent family children.

The main analysis compared the height, triceps skinfold, and weight for height of children of one and two parent families, adjusted by the selected social and biological variables using a multiple covariance analysis. Child's birthweight, parents' heights and weights were included in the models as continuous variables while child's ethnic origin was divided into white or other origin; number of siblings was divided into groups of fewer than 2 siblings, 2 or 3 siblings, and 4 or more siblings; and mother's education divided into five categories, elementary, secondary modern and comprehensive, commercial, grammar, university and professional. The first part of this analysis only included the children with complete information for all the independent variables. Response rates for these variables are shown in the Figure. The second part included the children with incomplete information for the independent variables. An extra category, for children with missing information, was created for number of siblings and mother's education. Missing data in the continuous variables were allowed for by using the analysis of covariance method. ${ }^{15}$ The missing items were replaced by the mean value of the variable, and an extra variable created, taking the value one for a child with the corresponding item of data missing, and zero for the rest. This automatically adjusted the dependent variable, in the covariance analysis, for different proportions of missing values in the one and two parent families when the dependent variable differed for children with incomplete information.

A further analysis was made of the weight measurements to determine whether the proportions of obese children were different in one and two parent families. The dependent variables were expressed as dichotomous variables whose cut-off points were defined as the 80th and 90th centile distribution of weight for height and triceps skinfold. Linear models were fitted using the program GLIM. $^{16}$

This program did not allow space for all the individual data points in this analysis and so continuous variables were categorised. The variables included were mother's weight/height index divided 
Table 1 Attained height, weight for height, and triceps skinfold of children expressed in SD score according to number of parents, country of residence, and gender

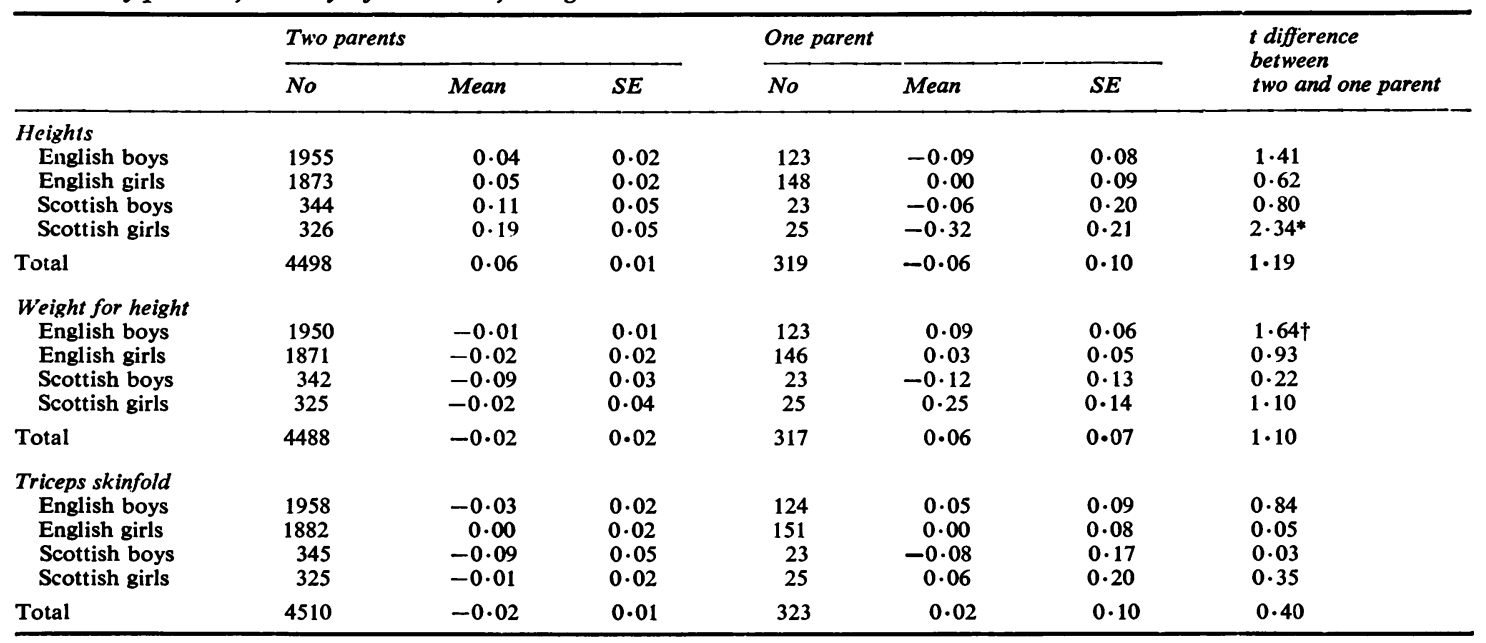

$\dagger \mathrm{P}<0.1 ; * \mathrm{P}<0.05$.

into four quartiles; child's birthweight divided into four groups, $1000-2500,2500-3000,3000-4000$, and $4000-5000 \mathrm{~g}$; mother's education and number of siblings were divided as in the previous analysis.

\section{Results}

Table 1 shows the mean measurements, expressed in SD scores of all children in the analysis, according to the number of parents living in the household, country of residence, and sex of the child.

In Scotland, girls from two parent families were significantly taller $(P<0.05)$ than those from one parent families. The remaining height measurements all showed non-significant differences, however children from two parent families were invariably taller than those from one parent families.

Mean weight for height and triceps skinfold measurements of the children showed there to be no significant differences between the one and two parent family children. The one parent family children however, had higher weight for height and triceps skinfold values with the exceptions of weight for height values of Scottish boys and triceps skinfold values for English girls.

The analysis of height expressed in SD scores in relation to age, sibship size, birthweight, mother's height, father's height, and mother's education showed similar associations in one and two parent family children. These associations were as reported by Rona et al. ${ }^{7}$ using information collected in 1972.

The analysis of the two weight measures, expressed in SD scores in relation to the social and biological factors showed similar associations in the one and two parent family children. These associations were as reported by Rona. ${ }^{14}$

Child's ethnic origin is a factor that has not previously been included in this type of analysis in the NSHG. Children of white origin had significantly higher triceps skinfold values than those from other origins $(P<0.001)$. Results showed similar trends for boys and girls considered separately. Weight for height measurements followed the same trend.

The children for whom information was lacking for independent variables were shorter than the children with complete information and formed a higher proportion of the one parent family group than the two parent group. Inclusion of these children by the methods described above led to similar regression coefficients of height SD scores on the other independent variables, and did not alter the difference between the one and two parent family group after adjustment. Results are therefore only presented for the multiple covariance analysis including all children, that is, children with incomplete and complete information. Tables 2 and 3 show the attained heights, weight for heights, and triceps skinfolds of children from one and two parent families in England and Scotland, expressed in SD scores, unadjusted and adjusted by the independent variables.

In England and Scotland there were no significant differences between the adjusted heights of the one and two parent family children. The test for nonparallelism of the regression planes for the two groups was significant for boys and girls, in England 
Table 2 Attained height, weight for height, and triceps skinfold expressed in SD scores according to number of parents living in the household in England unadjusted and adjusted by birthweight, number of siblings, mother's height, father's height, mother's education, and in the case of the weight measures child's ethnic origin and parents' weight, taking into account all children in the analysis

\begin{tabular}{|c|c|c|c|}
\hline & No & Unadjusted & Adjusted \\
\hline \multicolumn{4}{|l|}{$\begin{array}{l}\text { Heights } \\
\text { Boys }\end{array}$} \\
\hline $\begin{array}{l}\text { Two parent family } \\
\text { One parent family } \\
\text { Difference in means } \\
\text { Standard error of difference } \\
\text { Lack of parallelism }\end{array}$ & $\begin{array}{r}1955 \\
123\end{array}$ & $\begin{array}{l}0.043 \\
-0.089 \\
0.132 \\
0.087 \\
\text { N/A }\end{array}$ & $\begin{array}{r}0.040 \\
-0.030 \\
0.070 \\
0.084 \\
*\end{array}$ \\
\hline \multicolumn{4}{|l|}{ Girls } \\
\hline $\begin{array}{l}\text { Two parent family } \\
\text { One parent family } \\
\text { Difference in means } \\
\text { Standard error of difference } \\
\text { Lack of parallelism }\end{array}$ & $\begin{array}{r}1873 \\
148\end{array}$ & $\begin{array}{l}0.053 \\
0 \cdot 001 \\
0.052 \\
0 \cdot 080 \\
\text { N/A }\end{array}$ & $\begin{array}{r}0.044 \\
0 \cdot 113 \\
-0.069 \\
0.081 \\
* *\end{array}$ \\
\hline \multicolumn{4}{|l|}{$\begin{array}{l}\text { Weight for height } \\
\text { Boys }\end{array}$} \\
\hline $\begin{array}{l}\text { Two parent family } \\
\text { One parent family } \\
\text { Difference in means } \\
\text { Standard error of difference } \\
\text { Lack of parallelism }\end{array}$ & $\begin{array}{r}1950 \\
123\end{array}$ & $\begin{array}{l}-0.011 \\
0.090 \\
-0.101+ \\
0.060 \\
\text { N/A }\end{array}$ & $\begin{array}{r}-0.011 \\
0.084 \\
-0.095 \\
0.060 \\
\text { NS }\end{array}$ \\
\hline \multicolumn{4}{|l|}{ Girls } \\
\hline $\begin{array}{l}\text { Two parent family } \\
\text { One parent family } \\
\text { Difference in means } \\
\text { Standard error of difference } \\
\text { Lack of parallelism }\end{array}$ & $\begin{array}{r}1871 \\
146\end{array}$ & $\begin{array}{r}-0.023 \\
0.029 \\
-0.052 \\
0.057 \\
\text { N/A }\end{array}$ & $\begin{array}{r}-0.024 \\
0.032 \\
-0.056 \\
0.059 \\
\text { NS }\end{array}$ \\
\hline \multicolumn{4}{|l|}{$\begin{array}{l}\text { Triceps skinfold } \\
\text { Boys }\end{array}$} \\
\hline $\begin{array}{l}\text { Two parent family } \\
\text { One parent family } \\
\text { Difference in means } \\
\text { Standard error of difference } \\
\text { Lack of parallelism }\end{array}$ & $\begin{array}{r}1958 \\
124\end{array}$ & $\begin{array}{r}-0.025 \\
0.051 \\
-0.076 \\
0.091 \\
\text { N/A }\end{array}$ & $\begin{array}{l}-0.027 \\
0.081 \\
0.108 \\
0.093 \\
\text { NS }\end{array}$ \\
\hline \multicolumn{4}{|l|}{ Girls } \\
\hline $\begin{array}{l}\text { Two parent family } \\
\text { One parent family } \\
\text { Difference in means } \\
\text { Standard error of difference } \\
\text { Lack of parallelism }\end{array}$ & $\begin{array}{r}1882 \\
151\end{array}$ & $\begin{array}{r}-0.001 \\
0.004 \\
-0.005 \\
0.085 \\
\text { N/A }\end{array}$ & $\begin{aligned}-0.004 \\
0.049 \\
-0.053 \\
0.089 \\
\text { NS }\end{aligned}$ \\
\hline
\end{tabular}

N/A $=$ Not applicable, $\mathrm{NS}=$ non significant.

+ Significant $\mathrm{P}<0 \cdot 1,{ }^{*}$ significant $\mathrm{P}<0.05,{ }^{* *}$ significant $\mathrm{P}<0.01$.

( $\mathrm{P}<0.05, \mathrm{P}<0.01$ respectively), so that the differences in mean height between the two groups were not the same for all values of the independent variables. However, when the mean height for each group was adjusted to the overall mean of the independent variables using the separate regression equations for the one and two parent family groups the difference in adjusted mean heights for the boys was slightly less than that given in Table 2 . For girls this adjustment in height of the one parent family mean increased the adjusted mean height SD score to $\mathbf{0 \cdot 2 0 0}$. Therefore despite the significant lack of parallelism between one and two parent families in boys and girls, it still can be said that adjustment invariably meant an increase in the attained height
Table 3 Attained height, weight for height, and triceps skinfold expressed in $S D$ scores according to number of parents living in the household in Scotland unadjusted and adjusted by birthweight, number of siblings, mother's height, father's height, mother's education, and in the case of the weight measures child's ethnic origin and parents' weight, taking into account all children in the analysis

\begin{tabular}{|c|c|c|c|}
\hline & No & Unadjusted & Adjusted \\
\hline $\begin{array}{l}\text { Heights } \\
\text { Boys } \\
\text { Two parent family } \\
\text { One parent family } \\
\text { Difference in means } \\
\text { Standard error of difference } \\
\text { Lack of parallelism }\end{array}$ & $\begin{array}{r}344 \\
23\end{array}$ & $\begin{array}{r}0 \cdot 110 \\
-0 \cdot 057 \\
0 \cdot 167 \\
0 \cdot 207 \\
\text { N/A }\end{array}$ & $\begin{array}{l}0.085 \\
0.298 \\
-0.213 \\
0.206 \\
\text { NS }\end{array}$ \\
\hline $\begin{array}{l}\text { Girls } \\
\text { Two parent family } \\
\text { One parent family } \\
\text { Difference in means } \\
\text { Standard error of difference } \\
\text { Lack of parallelism }\end{array}$ & $\begin{array}{r}326 \\
25\end{array}$ & $\begin{array}{l}0 \cdot 186 \\
-0 \cdot 320 \\
0 \cdot 506^{*} \\
0 \cdot 198 \\
\text { N/A }\end{array}$ & $\begin{array}{l}0 \cdot 161 \\
-0 \cdot 003 \\
0 \cdot 164 \\
0 \cdot 187 \\
\text { NS }\end{array}$ \\
\hline $\begin{array}{l}\text { Weight for height } \\
\text { Boys } \\
\text { Two parent family } \\
\text { One parent family } \\
\text { Difference in means } \\
\text { Standard error of difference } \\
\text { Lack of parallelism }\end{array}$ & $\begin{array}{r}342 \\
23\end{array}$ & $\begin{array}{r}-0 \cdot 086 \\
-0 \cdot 118 \\
0 \cdot 032 \\
0 \cdot 125 \\
\text { N/A }\end{array}$ & $\begin{array}{l}-0.080 \\
-0.208 \\
0.128 \\
0 \cdot 146 \\
\text { NS }\end{array}$ \\
\hline $\begin{array}{l}\text { Girls } \\
\text { Two parent family } \\
\text { One parent family } \\
\text { Difference in means } \\
\text { Standard error of difference } \\
\text { Lack of parallelism }\end{array}$ & $\begin{array}{r}325 \\
25\end{array}$ & $\begin{array}{r}-0.020 \\
0.253 \\
-0.273 \\
0.139 \\
\text { N/A }\end{array}$ & $\begin{array}{l}-0.023 \\
0 \cdot 294 \\
-0 \cdot 317^{*} \\
0 \cdot 148 \\
\text { NS }\end{array}$ \\
\hline $\begin{array}{l}\text { Tricep skinfolds } \\
\text { Boys }\end{array}$ & & & \\
\hline $\begin{array}{l}\text { Two parent family } \\
\text { One parent family } \\
\text { Difference in means } \\
\text { Standard error of difference } \\
\text { Lack of parallelism }\end{array}$ & $\begin{array}{r}345 \\
23\end{array}$ & $\begin{array}{l}-0.088 \\
-0.083 \\
-0.005 \\
0.196 \\
\text { N/A }\end{array}$ & $\begin{array}{l}-0.074 \\
-0.297 \\
0.223 \\
0.233 \\
\text { NS }\end{array}$ \\
\hline $\begin{array}{l}\text { Girls } \\
\text { Two parent family } \\
\text { One parent family } \\
\text { Difference in means } \\
\text { Standard error of difference } \\
\text { Lack of parallelism }\end{array}$ & $\begin{array}{r}325 \\
25\end{array}$ & $\begin{array}{r}-0.013 \\
0.064 \\
-0.077 \\
0 \cdot 210 \\
\text { N/A }\end{array}$ & $\begin{array}{r}-0.023 \\
0.197 \\
-0.220 \\
0.231 \\
\text { NS }\end{array}$ \\
\hline
\end{tabular}

N/A $=$ not applicable, NS $=$ non significant.

* Significant $\mathrm{P}<0.05$.

values of the one parent family children. An examination of the adjusting factor showed that this was firstly a result of the high proportion of one parent family children with low birthweights $(10 \%$ of one parent family children had birthweights lower that $2500 \mathrm{~g}$ compared with $6 \%$ of two parent family children) and secondly a result of the high proportion with low values for parents' heights.

Adjusted weight for height and triceps skinfold values showed that in Scotland, girls from one parent families had significantly larger weight for height values $(P<0.05)$ and, although nonsignificant, larger triceps skinfold values. All other differences were not significant; however in England girls from one parent families had larger adjusted 
mean weight for height and triceps skinfold values than those from two parent families.

The results of the obesity analysis, comparing the proportions of obese one and two parent family children showed there to be no significant differences. In England, weight for height and triceps skinfold measurements showed that the one parent family children tended towards obesity with respect to both the 80th and 90th centiles, a higher proportion of one parent families falling into the 80th and 90th centiles than two parent family children. Trends were inconsistent for Scotland.

\section{Discussion}

Analysis of the height of the mother-headed one parent family children showed that although they were shorter, when adjustments were made for birthweight, number of siblings, mother's height, father's height, and mother's education, there were no significant differences in the heights of one and two parent family children. This indicated that the shorter stature of this group is associated with these social and biological factors rather than with the children's parental situation itself. An examination of the adjusting factors showed that low birthweights and shorter parents' heights accounted for the shorter stature of the one parent family children.

This type of finding was consistent with work done on a different aspect of one parent family children. Essen ${ }^{17}$ in 1979 using data from the National Child Development Study, following children between 7 and 17 years old, looked at school attainment of children who had spent any of their childhood in a one parent family. Children in one parent families had lower scores on test of attainment but after adjusting for background factors, particularly income, this was no longer the case for a reading test, and differences in mathematics were not significant. This confirmed work by Ferri ${ }^{18}$ in her study of the National Child Development Study children when they were eleven. Low scores in school attainment tests were related to social and financial circumstances rather than to the children's parental situation itself. In our analysis birthweight and parental height were associated with the shorter stature of one parent family children.

Analyses of weight for height and triceps skinfold measures indicated an increased likelihood of obesity among the one parent families. Findings of previous studies examining the nutritional status of one parent family children are contradictory and do not therefore substantiate a dietary explanation for this increased tendency towards obesity. The survey of children from one parent families in Newcastle upon Tyne ${ }^{19}$ showed that fatherless boys, but not girls, had a higher mean daily intake of energy, due to an increased intake of protein, fats, and carbohydrates, associated with a slightly greater mean height and arm muscle area. In contrast, in the study in Kent ${ }^{9}$ a higher proportion of obese children was found among the fatherless children. However these children had a better quality of diet $^{20}$ for although they had a lower average daily intake of energy and nutrients they had a higher intake of all nutrients/1000 kcal except for carbohydrate and added sugars.

This study has concentrated on the motherheaded one parent families, firstly as father-headed one parent families are in the minority, forming only $12 \%$ of all one parent families in Great Britain for the years 1977 to $1979^{1}$ and secondly, the circumstances of the father-headed families are different from those of the mother-headed families. Evidence from the literature shows that one parent families are twice as likely to have a low income if headed by a woman. ${ }^{21}$

The group being considered as the mother headed one parent families will consist of the widowed, separated, divorced, and single. We also know that a proportion of families change status from year to year, $14.8 \%$ of the one parent families in the NSHG had two parent family status and 1.9\% of the two parent families had one parent family status in 1978. The one parent families are known to experience different situations and each child in the analysis may have been experiencing very different environments for differing lengths of time. For example, it is known that widows and their families tend to be less dependent on Supplementary Benefit and free school meals, and are in general, better off than other fatherless families. ${ }^{2}$ Although, there may be a particular subgroup at greater disadvantage than the others, attempts to obtain information about one parent families and length of duration that they have been one parent families, might reduce response rates to the questionnaire. In Great Britain for the years 1977 to 1979, mother headed families were composed of $38 \%$ divorced, $24 \%$ separated, $19 \%$ widowed, and $19 \%$ single. ${ }^{1}$ We therefore assume that our results will apply to the majority of mother headed familiesthat is, the divorced and separated.

This study has shown that firstly, it is the high proportion of children from one parent families with low birthweights and shorter parents that is associated with the shorter stature of the one parent family children, factors that cannot be ignored in a consideration of the health and growth of these one parent family children, and secondly, the increased tendency towards obesity indicates that this may be a potential health problem among these children. 
We thank Professor W W Holland for encouragement and our colleagues who were involved in the National Study of Health and Growth; all doctors, nurses, and teachers in the study areas; the pupils and parents for their patient co-operation.

The study was supported by a grant from the Department of Health and Social Security and Scottish Home and Health Department.

\section{References}

1 Central Statistical Office. Social trends No 11. London: HMSO, 1981 : 27-44.

2 Finer M, chairman. The Finer Report. Report of the Committee on One Parent Families. London: HMSO, 1974.

3 Marsden D. Mothers alone: poverty and the fatherless family. London: Penguin, 1973.

4 Hunt A, Fox J, Morgan M. Families and their needs, with particular reference to one parent families. An enquiry carried out in 1970 by the Social Survey Division of the Office of Population Censuses and Surveys on behalf of the Department of Health and Social Security. London: HMSO, 1973.

5 Holman R. Unsupported mothers. London: Mothers in Action, 1970.

- Goldstein H. Factors influencing the height of seven year old children. Results from the National Child Development Study. Hum Biol 1971 ; 43: 92-111.

7 Rona R J, Swan A V, Altman D G. Social factors and height of primary schoolchildren in England and Scotland. $J$ Epidemiol Community Health 1978; 32: 147-54.

8 Lindgren G. Height, weight, and menarche in Swedish urban schoolchildren in relation to socio-economic and regional factors. Ann Hum Biol 1976; 3: 501-28.

9 Jacoby A, Altman D G, Cook J, Holland W W, Elliott A. Influence of some social and environmental factors on the nutrient intake and nutritional status of schoolchildren. Br J Prev Soc Med 1975; 29: 116-20.

10 Irwig L M. Surveillance in developed countries with particular reference to child growth. Int J Epidemiol 1976; 5: 57-61.

11 Chinn S, Morris R W. Standards of weight-for-height for English children from age 5.0 to 11.0 years. Ann Hum Biol 1980; 7: 457-71.

12 Morris R W, Chinn S. Weight for height as a measure of obesity in English children 5 to 11 years old. Int $J$ Obes 1981 ; 5: 359-66.

13 Rona R J, Altman D G. National Study of Health and Growth: standards of attained height, weight, and triceps skinfold in English children 5 to 11 years old. Ann Hum Biol 1977; 4: 501-23.

14 Rona R J. Genetic and environmental factors in the control of growth in childhood. Br Med Bull 1981; 37: 265-72.

15 Seber G A F. The linear hypothesis: a general theory. Griffin's statistical monographs and courses No 19. London: Griffin, 1966: 67-76.

16 Baker R J, Nelder J A. The GLIM system release. 3. Generalised interactive modelling. Oxford: Numerical Algorithms Group, 1978.

17 Essen J. Living in one-parent families: attainment at school. Child Care Health Dev 1979; 5: 189-200.

18 Ferri E. Growing up in a one-parent family. Windsor: National Foundation for Educational Research Publishing Company, 1976.

19 Darke S J, Disselduff M M, Try G P. A nutrition survey of children from one parent families in Newcastle upon Tyne in 1970. Br J Nutr 1980; 44: 237-41.

20 Cook J, Altman D G, Moore D M C, Topp S G, Holland W W, Elliott A. A survey of the nutritional status of schoolchildren: relation between nutrient intake and socio-economic factors. Br J Prev Soc Med 1973; 27: 91-9.

21 Van Slooten R, Coverdale A G. The characteristics of low income households. In: Social trends No 8. London: HMSO, 1977: 26-38.

Correspondence to Dr R J Rona, Department of Community Medicine, St Thomas's Hospital Medical School, Lambeth Palace Road, London SE1 7EH.

Received 31 December 1981 